\title{
Sosialisasi Dasar Teknik Instalasi Listrik Rumah Tangga di Kelurahan Kecamatan Trimurjo
}

\author{
Muhammad Putra Pamungkas ${ }^{1}$, Reni Permata Sari², Kusuma Wardany ${ }^{3 *}$, \\ Erni Mariana 4 \\ 1,2,3,4 Universitas Nahdlatul Ulama Lampung, J1. Raya Lintas Pantai Timur, \\ Purbolinggo, Kabupaten Lampung Timur, 34192, Indonesia \\ Email Korespondensi: kusuma.wardany@ymail.com
}

Diterima: Maret 2021; Revisi: April 2021; Diterbitkan: Juni 2021

\begin{abstract}
This service aims to increase the knowledge, awareness, and skills of the community, especially the residents of RT 26 Trimurjo Subdistrict, Trimurjo District on safety standards that need to be applied in household electrical installations. The method used is discussion and demonstration. The results of this activity include 1) This socialization activity has had an impact on the residents that it is important to know about the standardization of electrical installations in accordance with PUIL 2011. The activity took place well and in an orderly manner. Residents of RT 26 Trimurjo Subdistrict, Trimurjo Subdistrict, were enthusiastic in listening and discussing the socialization materials presented. Residents gave good feedback on the basic socialization of electrical installation techniques. And feel that there is a need to increase reliability and security in electrical installations, especially household electricity in the future.
\end{abstract}

Keywords: Installation, electrical, households, PUIL 2011, K3

\begin{abstract}
Abstrak
Pengabdian ini bertujuan untuk meningkatkan pengetahuan, kesadaran dan keterampilan masyarakat khususnya warga RT 26 Kelurahan Trimurjo Kecamatan Trimurjo akan standar keamanan yang perlu diterapkan dalam instalasi listrik rumah tangga. Metode yang digunakan adalah diskusi dan demistrasi. Hasil dari kegitan ini antara lain, 1) Kegiatan sosialisasi ini telah memberikan dampak terhadap warga bahwa pentingnya pengetahuan akan standarisasi instalasi listrik sesuai dengan PUIL 2011. Kegiatan berlangsung dengan baik dan tertib. Warga RT 26 Kelurahan Trimurjo Kecamatan Trimurjo antusias dalam menyimak, dan berdiskusi terhadap materi-materi sosialisasi yang disajikan. Warga memberikan feedback yang baik terhadap kegiatan sosialisasi dasar teknik instalasi listrik. Dan merasa bahwa perlu adanya peningkatan kehandalan, dan keamanan pada instalasi listrik khususnya kelistrikan rumah tangga kedepannya.
\end{abstract}

Kata Kunci: Instalasi, listrik, rumah tangga, PUIL 2011, K3

How to Cite: Pamungkas P.M., Sari P.R., Wardany K. dan Mariana E. (2021). Sosialisasi Dasar Teknik Instalasi Listrik Rumah Tangga di Kelurahan Kecamatan Trimurjo. SASAMBO: Jurnal Abdimas (Journal of Community Service). 3(2), 41-48. doi: 10.36312 / sasambo.v3i2.394 


\section{LATAR BELAKANG}

Salah satu kebutuhan pokok masyarakat urban saat ini adalah tenaga listrik. Tercatat pada Badan Pusat Statistik (BPS) Provinsi Lampung jumlah pelanggan listrik tahun 2015 sebesar 1.732.529 pelanggan (BPS, 2015). Dan kebutuhan tenaga listrik akan terus meningkat seiring peningkatan jumlah pemukiman. Hal ini didukung pemerintah melalui program pemerintah yaitu listrik masuk desa (Kali, 2011).

Dengan semakin padatnya pemukiman penduduk beberapa masalah akan timbul, khususnya dalam hal instalasi listrik.Permasalahan yang kerap muncul adalah hubungan arus pendek (korsleting listrik) yang akan mengakibatkan kebakaran. Badan Statistika milik Pemerintah Daerah Jakarta mengumumkan pada tahun 2019 rata-rata $70 \%$ penyebab kebakaran di beberapa kota di Jakarta disebabkan oleh korsleting listrik (Sudiana et al., 2019) dan (Amra et al., 2018). Korsleting listrik yang terjadi umumnya disebabkan oleh adanya kabel instalasi yang memuat arus listrik melebihi kapasitas kabelnya. Sehingga menyebabkan kabel yang terbakar kemudian bunga api menjalar ke benda-benda yang mudah terbakar di dalam rumah. Kesalahan pemilihan jenis kabel yang sesuai dengan kebutuhan penggunaan daya listrik ini umumnya disebabkan kurangnya kesadaran masyarakat pada saat instalasi listrik (Elchrisa et al., 2019), (Seniari et al., 2019).

Dalam hal perancangan, pemasangan, dan perawatan instalasi listrik terdapat beberapa hal yang perlu diperhatikan yaitu diantaranya keamanan, kehandalan, kemudahan diakses, ketersediaan, dan nilai ekonomis, khususnya dalam hal keamanan. Hal ini harus dititik beratkan pada keamanan dan keselamatan manusia, makhluk hidup, dan bendabenda berharga disekitar (Binoto et al., 2012). Pemerintah Republik Indonesia melalui Badan Standarisasi Nasional telah menerbitkan Persyarat Umum Instalasi Listrik (PUIL) sejak tahun 1964. Dengan PUIL edisi terbaru merupakan PUIL 2011. Didalam buku tersebut pemerintah melalui BSN memberikan rekomendasi-rekomendasi terkait perancangan, keamanan, kelayakan, dan perawatan instalasi listrik mulai dari kebutuhan listrik rumah tinggal hingga kebutuhan listrik pada industri (Badan Standardisasi Nasional, 2011).

Warga desa terutama bapak-bapak dan pemuda di Kelurahan Trimurjo RT 26 biasa menggunakan jasa pekerja pemasangan listrik ketika mereka hendak bekerja, walaupun mereka terkadang mampu mengerjakan sendiri pemasangan listrik di rumahnya. Ketika pekerja membantu memasang instalasi listrik di rumahnya dalam penambahan titik lampunya belum mempunyai manajemen kerja yang bagus. Sering sekali pekerja bongkarpasang berkali-kali sehingga banyak ada waktu dan material terbuang percuma. Terkadang situasi seperti ini membuat warga merasa rugi. Beberapa bahan yang dipasang seperti kabel, saklar, stopkontak dan lain sebagainya sering tidak memenuhi standar sehingga bagi warga yang jeli, bahan-bahan instalasi dipilih dan dibeli oleh warga sendiri. Para pekerja terkesan sangat berani dalam mengerjakan pekerjaan instalasi listrik di atas flapon tanpa menghiraukan keselamatan dirinya. Terkesan seperti tidak takut dengan kecelakaan yang bisa terjadi. Berdasarkan hal tersebut, warga ingin sekali mendapat pengetahuan tentang instalasi listrik rumah tangga yang terstandarisasi seuai PUIL 2011 serta aspek K3 (Keselamatan 
dan Kesehatan Kerja) sebab warga di Kelurahan Trimurjo khususnya warga RT 26, masih memiliki pengetahuan akan teknik dasar instalasi listrik rumah tangga yang rendah.

Dengan diadakannya kegiatan sosialisasi tersebut diharapkan mampu meningkatkan kesadaran warga RT 26 Kelurahan Trimurjo, Trimurjo serta meningkatkan standar keamanan dalam instalasi listrik. Selain itu luaran yang ingin dicapai dari sosialisasi dasar teknik instalasi listrik adalah pengetahuan dasar kelistrikan, manajemen penggunaan listrik, serta meningkatkan keterampilan teknis pada instalasi listrik, khususnya listrik rumah tangga (Kartika Sekarsari et al., 2020). Kegiatan pengabdian ini diharapkan masyarakat dapat mengenal instalasi listrik yang benar sesuai standar PUIL 2011, sehingga tidak terjadi bahaya baik terhadap manusia maupun bangunannya serta masyarakat mampu menghemat energi listrik (Janardana et al., 2018).

\section{METODE PELAKSANAAN}

Metode pelaksanaan didasarkan pada proses yang membangun manusia atau masyarakat melalui pengembangan kemampuan masyarakat, perubahan perilaku masyarakat, dan pengorganisasian masyarakat. Menurut (Ulumiyah, 2013) 3 tujuan utama dalam pemberdayaan masyarakat, yaitu mengembangkan kemampuan masyarakat, mengubah perilaku masyarakat, dan mengorganisir diri masyarakat. Subjek (mitra) dari pengabdian ini adalah warga RT 26 Kelurahan Trimurjo, Trimurjo, Kab Lampung Tengah berjumlah 12 orang. Dalam kegiatan ini digunakan beberapa metode di antaranya: penyuluhan (sosialisasi) berupa ceramah dan diskusi.

Adapun tahapan atau langkah-langkah sosialisasi di awali sebagai berikut:

1. Koordinasi dengan mitra tentang jenis kegiatan yang akan dilaksanakan, jadwal pelaksanaan, dan tempat pelaksanaan kegiatan via telepon.

2. Konsultasi via telepon Sebelum materi ceramah secara online (via telepon) dimulai, peserta akan diwawancarai via telepon terlebih dahulu untuk mengetahui sejauh mana pemahamannya tentang instalasi listrik, data yang didapatkan ini dipakai pedoman untuk pemberian materi ceramah.

3. Melakukan pengamatan/obervasi kondisi instalasi kelistrikan langsung pada rumah-rumah warga.

4. Sosialisasi dan dilakukan ditempat yang telah disepakati, tempat disesuaikan dengan materi

5. Hasil evaluasi dianalisis oleh penulis/ pengusul kegiatan pengabdian untuk mengetahui pemahaman dan antusias warga dalam proses sosialisasi

Secara singkat rangkaian proses kegiatan sosialisasi ini adalah sebagai berikut: 


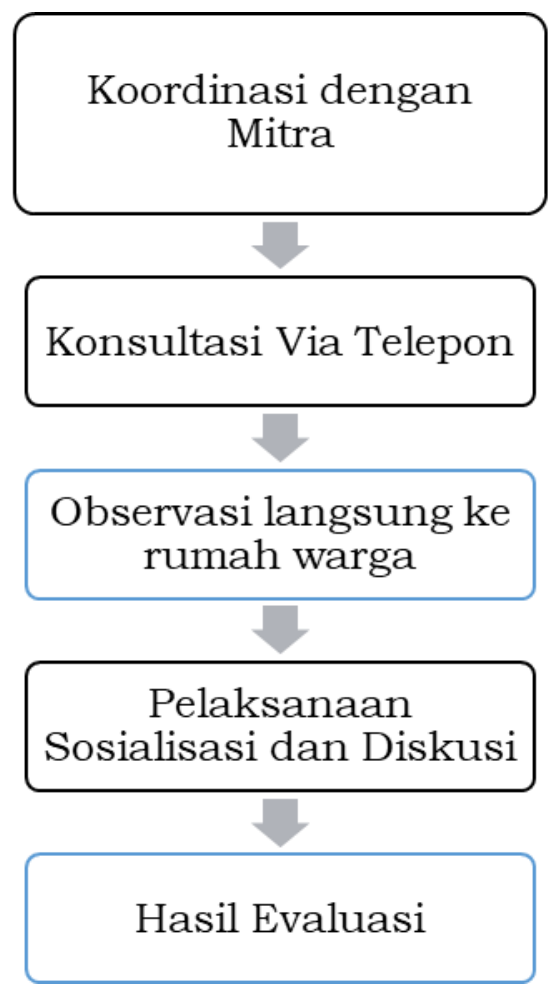

Gambar 1. Tahapan sosialisasi

\section{HASIL DAN PEMBAHASAN}

Sosialisasi mengenai dasar-dasar teknik instalasi listrik pada rumah tangga bagi Warga RT 26 Kelurahan Trimurjo Kecamatan Trimurjo, telah dilaksanakan pada 10 Februari 2021 dan bertempat di kediaman Ketua RT 26. Kegiatan tersebut terlaksana dengan peserta sejumlah 12 orang. Kegiatan tersebut dilaksanakan dengan metode ceramah dan diskusi.

Penyampaian materi sosialisasi diawali dengan diskusi santai terkait teknis-teknis instalasi listrik antara panelis dengan pendengar. Hal ini dilakukan agar warga paham dan sadar akan pentingnya standarisasi instalasi listrik, khususnya instalasi listrik pada rumah tangga. Sekaligus untuk mengetahui kendala-kendala yang dihadapi warga dalam proses perancangan, pemasangan dan perawatan instalasi listrik rumah tangga.

Tahap pertama, penyampaian materi terkait standar instalasi listrik yang telah ditetapkan pemerintah yang tertuang dalam Persyaratan Umum Instalasi Listrik 2011 (Badan Standardisasi Nasional, 2011). Tahap ini menyampaikan hal-hal penting di dalam PUIL 2011 yang berkaitan dengan instalasi listrik rumah tangga.

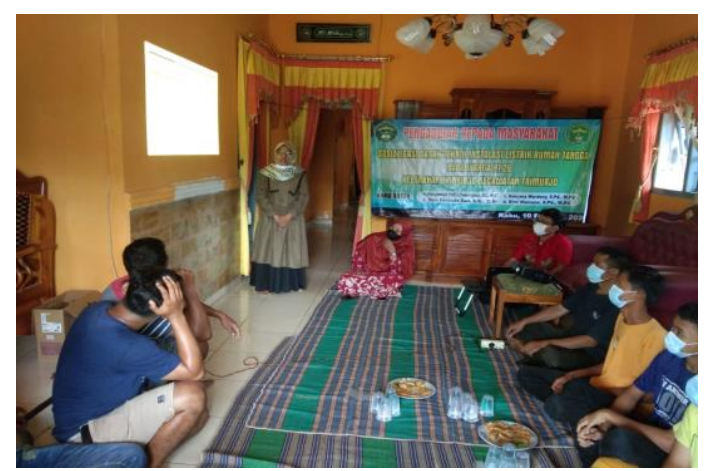

Gambar 2. Penyampaian materi 
Tahap kedua, penyampaian materi terkait bagaimana merancang instalasi listrik rumah tangga baik instalasi baru maupun menganalisis rancangan yang telah terpasang. Memahami rancangan instalasi listrik menjadi penting dikarenakan dengan mengetahui rancangan instalasi listrik suatu bangunan petugas ahli kelistrikan maupun penghuni akan lebih mudah melakukan pemasangan dan perawatan. Salah satu contoh merancang instalasi listrik rumah adalah dengan menggunakan skema diagram 1 kabel (single line diagram) dan diagram pengabelan (wiring diagram)
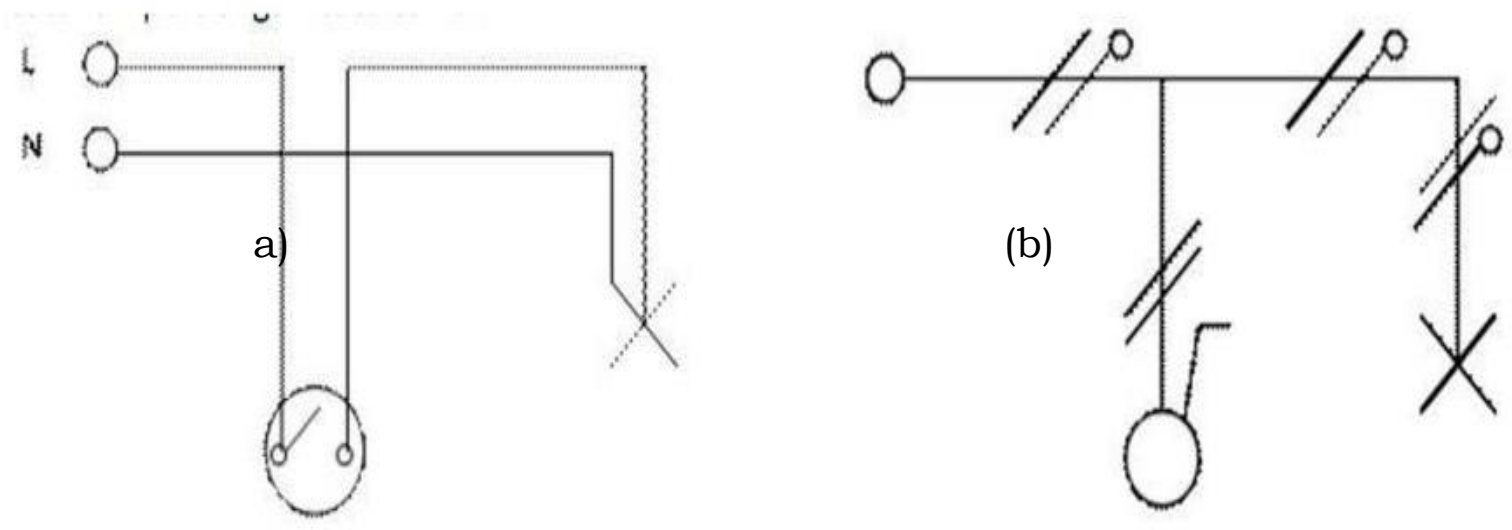

Gambar 3. Contoh perancangan instalasi listrik (a) wiring diagram, dan (b) Single Line Diagram

Tahap ketiga, penyampaian terkait keselamatan dan kesehatan kerja (K3) dalam proses instalasi dan perawatan kelistrikan rumah tangga. Keselamatan kerja menjadi aspek yang penting dalam penanganan kelistrikan khususnya di rumah tangga mengingat banyak terjadinya kecelakaan kerja terjadi ketika pengguna tidak memerhatikan perlengkapan kerja yang aman dalam standar teknis instalasi listrik.

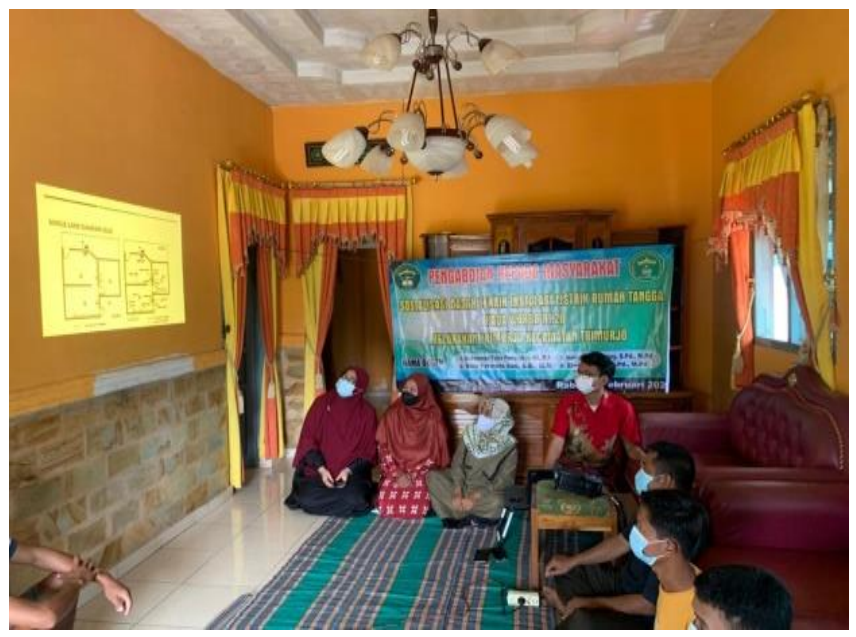

Gambar 4. Penyampaian materi perancangan instalasi listrik dan K3 
Tahap keempat, sosialisasi percobaan atau praktik pemasangan maupun perawatan instalasi listrik.

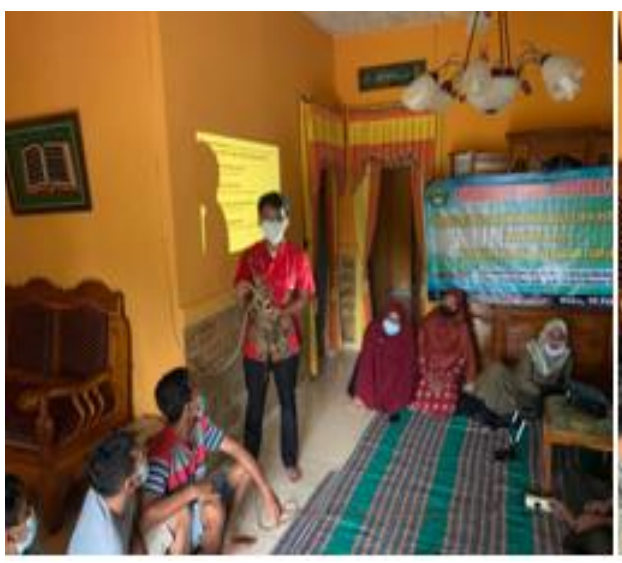

(a)

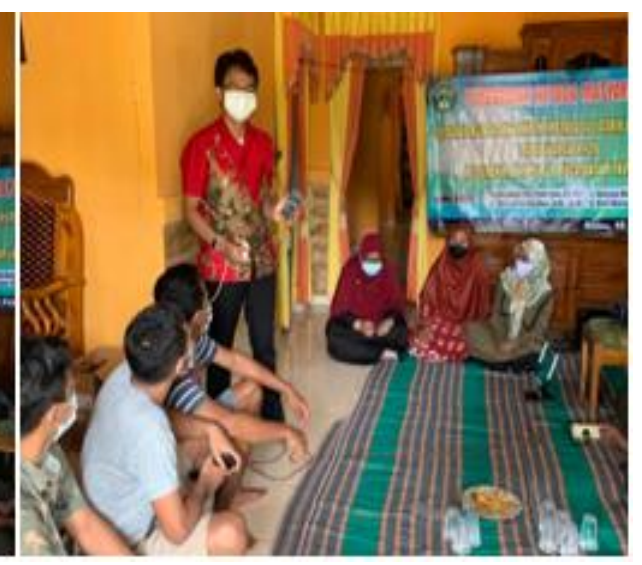

(b)

Gambar 5. (a) dan (b) Pemateri menjelaskan percobaan atau praktik pemasangan maupun perawatan instalasi listrik

Adapun rangkaian acara sosialisasi kegitan pengabdian disajikan seperti apada tabel sebagai berikut :

Tabel 1. Rangkaian Sosialisasi kegiatan Pengabdian

\begin{tabular}{|c|c|c|c|}
\hline No. & Waktu (WIB) & Agenda Kegiatan & Penanggung Jawab \\
\hline 1. & $08.00-08.30$ & Registrasi & Panitia \\
\hline 2. & $08.31-08.45$ & Pembukaan & Ketua RT \\
\hline 3. & $08.46-09.30$ & $\begin{array}{l}\text { Penjelasan mengenai standar } \\
\text { Instalasi Listrik } \\
\text { (PUIL 2011) }\end{array}$ & $\begin{array}{l}\text { Reni Permata Sari, } \\
\text { S.Si., M.Si. }\end{array}$ \\
\hline 4. & $09.31-10.20$ & $\begin{array}{l}\text { Penjelasan mengenai pentingnya } \\
\text { perancangan Instalasi Listrik }\end{array}$ & $\begin{array}{l}\text { Erni Mardiana, } \\
\text { S.Pd., M.Pd. }\end{array}$ \\
\hline 5. & $10.21-11.00$ & $\begin{array}{l}\text { Penjelasan mengenai K3 dalam } \\
\text { Instalasi Listrik }\end{array}$ & $\begin{array}{l}\text { Kusuma Wardany, } \\
\text { S.Pd., M.Pd. }\end{array}$ \\
\hline 6. & $11.00-12.30$ & Istirahat & Panitia \\
\hline 7. & $12.31-14.30$ & $\begin{array}{l}\text { Penjelasan mengenai Teknik } \\
\text { Pemasangan/Perawatan } \\
\text { instalasi listrik rumah tangga }\end{array}$ & $\begin{array}{l}\text { Muhammad Putra } \\
\text { Pamungkas, S.T., } \\
\text { M.T. }\end{array}$ \\
\hline 8. & $14.31-15.00$ & Diskusi dan evaluasi kegiatan & $\begin{array}{l}\text { Seluruh komponen } \\
\text { kegiatan }\end{array}$ \\
\hline 9. & $15.01-15.15$ & Penutup & Panitia \\
\hline
\end{tabular}

Secara keseluruhan kegiatan sosialisasi yang telah dilakukan, diperoleh hasil sebagai berikut :

a. Kegiatan berlangsung dengan baik dan tertib. Warga RT 26 Kelurahan Trimurjo Kecamatan Trimurjo antusias dalam menyimak, dan berdiskusi terhadap materi-materi sosialisasi yang disajikan.

b. Warga memberikan feedback yang baik terhadap kegiatan sosialisasi dasar teknik instalasi listrik, dan merasa bahwa perlu adanya peningkatan kehandalan, dan keamanan pada instalasi listrik khususnya kelistrikan rumah tangga kedepannya. 


\section{KESIMPULAN}

Berdasarkan hasil dan pembahasan pada sosialisasi dasar teknik instalasi listrik kepada Warga RT 26 Kelurahan Trimurjo Kecamatan Trimurjo, dapat disimpulkan bahwa pengetahuan masyarakat, khususnya warga RT 26 Kelurahan Trimurjo Kecamatan Trimurjo atas Persyaratan Umum Instalasi Listrik (PUIL) 2011 masih rendah. Kegiatan sosialisasi ini telah memberikan dampak terhadap warga bahwa pentingnya pengetahuan akan standarisasi instalasi listrik sesuai dengan PUIL 2011. Kegiatan berlangsung dengan baik dan tertib. Warga RT 26 Kelurahan Trimurjo Kecamatan Trimurjo antusias dalam menyimak, dan berdiskusi terhadap materi-materi sosialisasi yang disajikan. Warga memberikan feedback yang baik terhadap kegiatan sosialisasi dasar teknik instalasi listrik. Dan merasa bahwa perlu adanya peningkatan kehandalan, dan keamanan pada instalasi listrik khususnya kelistrikan rumah tangga kedepannya.

\section{REKOMENDASI}

Dari Hasil kegiatan ini perlu kiranya dilakukan pelatihan secara khusus atau pelatihan lainnya yang lebih intensif untuk lebih meningkatkan keahlian para peserta. Dalam kegiatan sosialisasi ini tidak terdapat hambatan, dan kegiatan berjalan dengan baik serta dari pemateri maupun peserta terjalin komunikasi dengan baik.

\section{DAFTAR PUSTAKA}

Amra, S., Rachmawati, Safitri, N., \& Misriana. (2018). Pelatihan Pemasangan Instalasi Listrik Rumah Tinggal bagi Pemuda Desa Alue Lim Kecamatan Blang Mangat Kota Lhoseumawe. Proceeding Seminar Nasional Politeknik Negeri Lhokseumawe.

Badan Standardisasi Nasional. (2011). Persyaratan Umum Instalasi Listrik 2011 (PUIL 2011). In DirJen Ketenagalistrikan.

Binoto, M., Yudaningtyas, E., \& Wijono. (2012). Peramalan Beban Listrik Jangka Pendek Menggunakan Jaringan Syaraf Tiruan Di Kabupaten Karanganyar - Jawa Tengah. Jurnal ELTEK.

BPS. (2015). Statistik Indonesia 2015. In Statistik Indonesia.

Elchrisa, C., Amali, L. K., \& Tolago, A. I. (2019). Analisis Optimasi Penempatan Kapasitor Bank pada Jaringan Tegangan Menengah 20kV Feeder IS.03 Rayon Limboto untuk Memperbaiki Kualitas Tegangan. Jambura Journal of Electrical and Electronics Engineering. https://doi.org/10.37905/jjeee.v1i1.2725

Janardana, I. G. N., Arta Wijaya, I. W., Budiastra, N., Sukerayasa, W., \& Ariastina, W. G. (2018). Sosialisasi Keamanan Sistem Instalasi Listrik Dan Hemat Energi Di Banjar Tingkih Kerep - Penebel Tabanan. Buletin Udayana Mengabdi. https://doi.org/10.24843/bum.2018.v17.i04.p03

Kali, A. (2011). Analisis Partisipasi Masyarakat Terhadap Perencanaan Dan Pembangunan PLTMH Di Paneki Desa Pombewe Kecamatan Biromaru Kabupaten Sigi. Mektek.

Kartika Sekarsari, Heri Kusnadi, Sunardi, \& Oky Supriadi. (2020). Pemberdayaan Masyarakat di Wilayah Benda Baru Melalui Pelatihan Instalasi Listrik Rumah Tangga. Dinamisia : Jurnal Pengabdian Kepada Masyarakat. https://doi.org/10.31849/dinamisia.v4i3.4016

Seniari, N. M., Supriyatna, S., Natsir, A., Adnyani, I. A. S., \& Nababan, S. (2019). Pelatihan Pemasangan Instalasi Listrik Rumah Tangga Yang 
Aman Bagi Warga Kelurahan Pagutan Barat Kota Mataram. Abdi Insani. https://doi.org/10.29303/abdiinsani.v6i1.219

Sudiana, N., Rovara, O., \& Astisiasari, A. (2019). Analisis Potensi Bahaya Bencana Kebakaran Perkotaan Di Provinsi Dki Jakarta. Jurnal Sains Dan Teknologi Mitigasi Bencana. https://doi.org/10.29122/jstmb.v13i2.2904

Ulumiyah, I. (2013). Peran Pemerintah Desa Dalam Memberdayakan Masyarakat Desa (Studi Pada Desa Sumberpasir Kecamatan Pakis Kabupaten Malang). Jurnal Administrasi Publik Mahasiswa Universitas Brawijaya. 